\title{
NASELJENOST SJEVERNOG I SREDNJEG VELEBITA U PRAPOVIJESTI I ANTICI
}

Vedrana Glavaš

Miroslav Glavičić

Odjel za arheologiju

Sveučilište u Zadru

Obala kralja Petra Krešimira IV., 2

HR 23000 Zadar

vglavas@unizd.hr

glavicic@unizd.hr
UDK: 902/904(497.5 Velebit)“652““

Pregledni članak

Ur.: 2017-04-06

U radu se donose rezultati istraživanja prapovijesne i antičke naseljenosti na prostoru sjevernog i srednjeg Velebita. Istraživanje naseljenosti samo je jedan segment multidisciplinarnog istraživanja kulturnog krajolika, koje se na studijskom prostoru provodi posljednjih deset godina. Metodologija istraživanja je kompleksna, a obuhvaća intenzivne terenske preglede, zračna snimanja, GIS analize i arheološka iskopavanja.

Prapovijesni naseobinski obrazac karakteriziraju gradine, kojih je do sada na studijskom prostoru dokumentirano 36. Iako se u ranijoj literaturi većinom tretiraju kao mjesta za stanovanje, na 36 podvelebitskih gradina nisu dokumentirane naseobinske aktivnosti. Osnovne arhitektonske strukture karakteristične za podvelebitske gradine su bedemi i terase.

Prostorno decentraliziran obrazac gradina u podvelebitskom primorju nakon uspostave rimske uprave centralizira se, a podno velebitskih prijevoja razvijaju se municipalna središta: Senia, Lopsica, Ortopla i Vegium. Pri tom Senija ostvaruje vodeću gospodarsku, trgovačku i prometnu ulogu regionalnog značenja, dok će ostala naselja zadržati samo lokalno značenje.

Ključne riječi: Velebit, prapovijest, gradine, antika, naseljenost

Glavna obilježja primorskog obronka Velebita su oskudnost resursa i sušnost što je znatno utjecalo na naseljenost i korištenje prostora tijekom povijesti. Iako je izgledom tipični mediteranski krajolik, Podgorje je zapravo vrlo surovo područje, gdje su ljudi tijekom prošlosti činili velike napore da ga oblikuju i formiraju radi vlastitog opstanka. Upravo je takav doživljaj Velebita glavni razlog što će ova planina ostati izvan većeg interesa arheologa, jer pretpostavlja se da oskudni prirodni resursi znače ujedno i smanjenu prisutnost ljudi tijekom različitih 
povijesnih razdoblja. Međutim, ljudi su na prostoru Velebita živjeli tijekom svih povijesnih razdoblja oblikujući kulturni krajolik, a da bi preživjeli u takvom prirodnom okolišu, prilagođavali su se topografiji i klimi, te dostupnim, ali veoma oskudnim, resursima. Pri tom su rekreirali prostor s obzirom na vlastite potrebe i razmišljanja, na politiku i društvenu dinamiku, koristeći svoja znanja ili tehnološke resurse čime su uvelike mijenjali krajolik.

Područje istraživanja ovog rada fokusirano je na primorsku padinu sjevernog i srednjeg Velebita, koju okvirno markiraju prijevoji Vratnik (694 m n. v.) iznad Senja i Baške Oštarije (927 m n.v.) iznad Karlobaga. Osnovni cilj rada je prikazati preliminarne rezultate istraživanja kulturnog krajolika sjevernog i srednjeg Velebita.

\section{Metodologija istraživanja}

Istraživanje naseljenosti sjevernog i srednjeg Velebita predstavljeno u ovom radu samo je jedan segment kompleksnog istraživanja kulturnog krajolika koje se ovdje intenzivno provodi posljednjih desetak godina. ${ }^{1}$ Istraživanje je multidisciplinarno, a obuhvaća terenski pregled, zračna snimanja, upotrebu Geografskog informacijskog sustava (GIS) za pohranjivanje, obradu podataka i prostorne analize te arheološka iskopavanja.

Terenski pregled podvelebitskog primorja provodi se sustavno da bi se otkrili i dokumentirali novi lokaliteti, ${ }^{2}$ ali isto tako da bi se prikupile dodatne informacije o onim lokalitetima koji su već poznati u stručnoj literaturi. ${ }^{3}$ Pri tom se intenzivno vrše i zračna snimanja, koja su izvanredna metoda prospekcije kulturnog krajolika ${ }^{4}$

S obzirom na površinu prostora i broj arheoloških lokaliteta, u Podgorju je arheološki istraživano svega nekoliko lokaliteta. ${ }^{5} \mathrm{Zbog}$ toga su nedavno pokrenuta sustavna iskopavanja gradine Drvišica u Karlobagu veoma značajna, ${ }^{6}$ a usmjerena su na definiranje stratigrafije te istraživanje svrhe i karaktera gradinskih lokaliteta.

${ }^{1}$ V. GLAVAŠ, 2009, 67-82; 2010, 5-18; 2011, 24-29; 2014, 1-26; 2015; V. GLAVAŠ - R. PALMER, 2013, 19-23; V. GLAVAŠ - A. GRLJ, 2016, 65-81.

${ }^{2}$ V. GLAVAŠ - R. PALMER, 2013, 19-23.

${ }^{3}$ A. GLAVIČIĆ, 1966, 383-418; 1967-1968, 5-45; 1970, 45-70; 1980, 171-186; 1981-1982, 33-42; 1984, 7-28; M. GLAVIČIĆ, 1991-1992, 97-119.

${ }^{4} \mathrm{Za}$ zračna snimanja koriste se ultralake letjelice, a za detaljnije fotografiranje pojedinih nalazišta dronovi.

${ }^{5}$ M. BLEČIĆ, 2006, 5-26; J. BRUNŠMID, 1898, 171-177; 1901, 53-62; S. FORENBAHER, 1991, 217-225; V. GLAVAŠ, 2009, 67-82; A. GLAVIČIĆ, 1975, 211-218; M. GLAVIČIĆ, 1995, 1-28; 1995b, 29-80; B. LJUBOVIĆ, 2008, 279-292. i drugi.

${ }^{6}$ Istraživanja koja su započeta 2013. godine financiraju Ministarstvo kulture Republike Hrvatske i Općina Karlobag. 


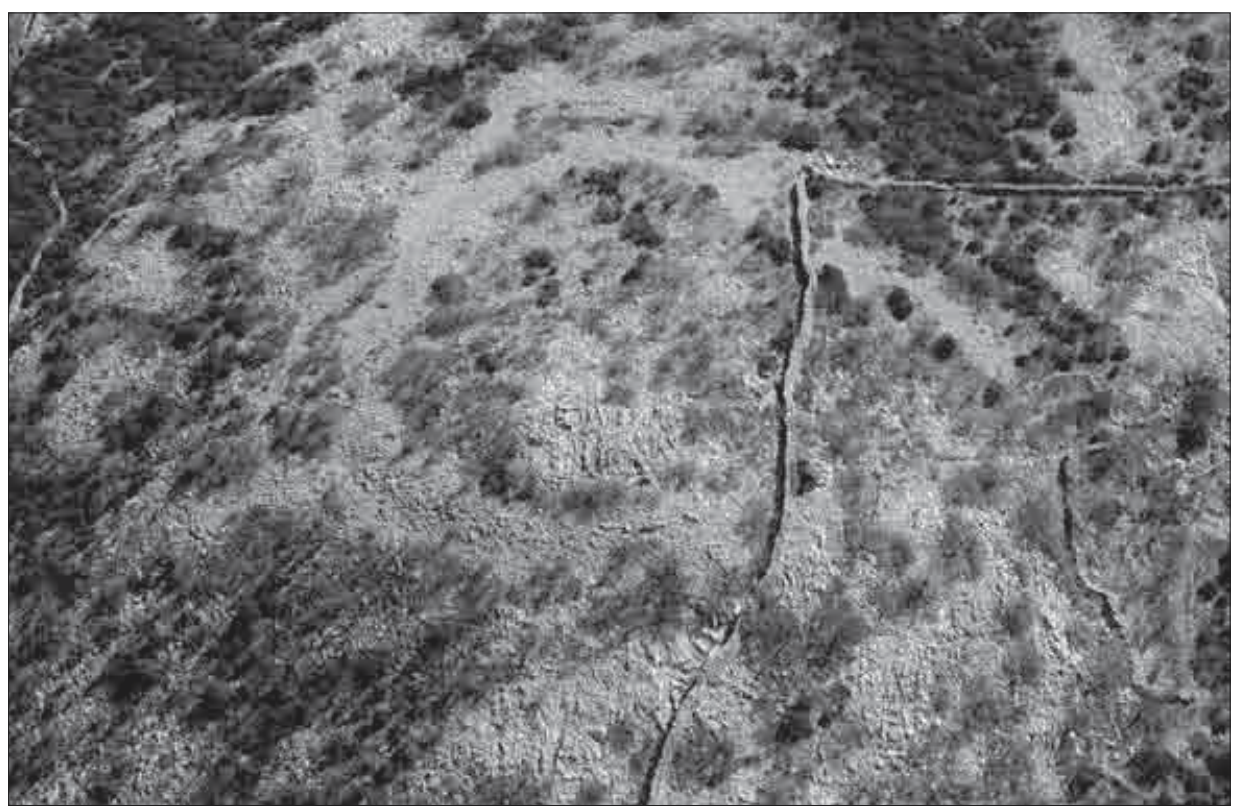

Sl. 1. Gradina Bela kosa u Ivanči, foto: V. Glavaš

Svi podatci prikupljeni terenskim pregledom, zračnim snimanjem i arheološkim iskopavanjem unose se u prostornu bazu podataka izrađenu u ESRI ArcGIS programskom paketu što omogućuje i provođenje prostornih analiza. Za ovaj rad provedene su analize gustoće naseljenosti, analize nadmorskih visina lokaliteta te analize vidljivosti. GIS se u ovom istraživanju upotrebljava i za dokumentiranje i kartiranje svih struktura kulturnog krajolika (zidovi, osipine, lokve i sl.).

\section{Prapovijesni kulturni krajolik}

Gledajući s aspekta naseljenosti, prapovijesni kulturni krajolik Podgorja možemo promotriti kroz krajolik gradina. Iako su se tijekom prapovijesnih razdoblja kao privremena skloništa koristile i špilje, ${ }^{7}$ ipak su gradine najčešći lokaliteti dokumentirani na istraživanom prostoru. Gradine su većinom formirane na uzvišenim pozicijama i uglavnom se smatraju prapovijesnim naseljima. ${ }^{8}$ Međutim, treba naglasiti da na većini gradina podvelebitskog primorja nema

${ }^{7}$ S. FORENBAHER - P. VRANJICAN, 1985, 1-21; S. FORENBACHER, 1991, 217-225.

${ }^{8}$ Š. BATOVIĆ, 1987, 351-352. 
dokaza habitacije i zato su razlozi njihove izgradnje ponekad nejasni. ${ }^{9}$ Do sada je na studijskom području otkriveno ukupno 36 lokaliteta gradinskog tipa. ${ }^{10}$

Analizom podataka utvrđeno je da su kao ključne prostorne determinante za izgradnju gradine bili planinski prijevoji, izvori sedimenta (vrtača, dolac) i izvori pitke vode. ${ }^{11}$ Budući da je pitka voda bila najznačajniji čimbenik pri odabiru lokacije, gradine su u podvelebitskom primorju uglavnom smještene linearno u blizini morske obale, gdje je bio najveći broj izvora. ${ }^{12}$ Zbog toga se položaji gradina još uvijek ne mogu koristiti za rekonstrukciju prapovijesnih stočarskih kretanja. Isto tako, nepoznate su pozicije i izgled privremenih sezonskih staništa na višim nadmorskim visinama, gdje se tijekom ljetnih mjeseci napasala stoka.

Bedemi i terase su osnovne gradinske arhitektonske strukture koje gradinama daju sliku monumentalnosti u okolnom krajoliku. Bedemima se posvećivala posebna pažnja, jer njihova je osnovna funkcija bila obrambena. Međutim, njihove debljine variraju od $1 \mathrm{~m}$ do 3,5 $\mathrm{m}$, a sačuvane su u visinu do 1,49 $\mathrm{m} .{ }^{13}$ Bedemi su građeni u suhozidnoj tehnici od većih i manjih kamenih blokova, koji su ili neobrađeni ili samo grubo obrađeni (Sl.2). Danas su uglavnom sačuvani kao suhozidne osipine rasute niz padinu brda, ali dokumentirani su gdjegdje $\mathrm{i}$ dobro sačuvani dijelovi bedema (npr. na gradini Klačnici u Jablancu). ${ }^{14}$ Bedemi su redovito sagrađeni na blago položitim i lako pristupnim mjestima, dok ih iznad klisura i jaruga uglavnom nema. Druga značajna arhitektonska tvorevina karakteristična za gradine su terase, koje čini potporni zid i zemljana ili kamena ispuna kojom se teren iznivelira u ravnu površinu. Njihova je namjena primarno $\mathrm{u}$ funkciji nivelacije terena i stvaranja dodatne površine za obavljanje nekih drugih, npr. poljoprivrednih aktivnosti, iako sekundarno može biti i obrambena. ${ }^{15}$

Istaknuti položaj gradina omogućavao je njihovu međusobnu vizualnu komunikaciju u prostoru. Rezultati istraživanja vidljivosti, koja su provedena na prostoru Velebita, u kojima je proučeno kako su stanovnici Podgorja u prapovijesti kontrolirali plovidbu morskim kanalom i nadzirali ekonomske

\footnotetext{
${ }^{9}$ V. GLAVAŠ, 2015, 70-142.

${ }^{10}$ M. GLAVIČIĆ, 1991-1992, 97-119; V. GLAVAŠ, 2014, 1-26; 2015, 462-490.

${ }^{11}$ V. GLAVAŠ, 2015, 87-88.

${ }^{12} \mathrm{Na}$ studijskom području najviša nadmorska visina na kojoj je dokumentirana neka gradina iznosi 369,5 m (Bela kosa u Ivanči). V. GLAVAŠ, 2015, 92.

${ }^{13}$ Bedem gradine Drvišice u Karlobagu pruža se hrptom grebena u dužini cca 390 m. Njegova istraživanjem utvrđena najveća visina iznosi $1,49 \mathrm{~m}$, a širina do 3,5 $\mathrm{m}$ na pojedinim mjestima.

${ }^{14}$ V. GLAVAŠ, 2015, 72.

${ }^{15}$ Za razliku od bedema, koji nisu dokumentirani na svim lokalitetima, terase su sagrađene na svim gradinama podvelebitskog primorja. V. GLAVAŠ, 2015, 75.
} 


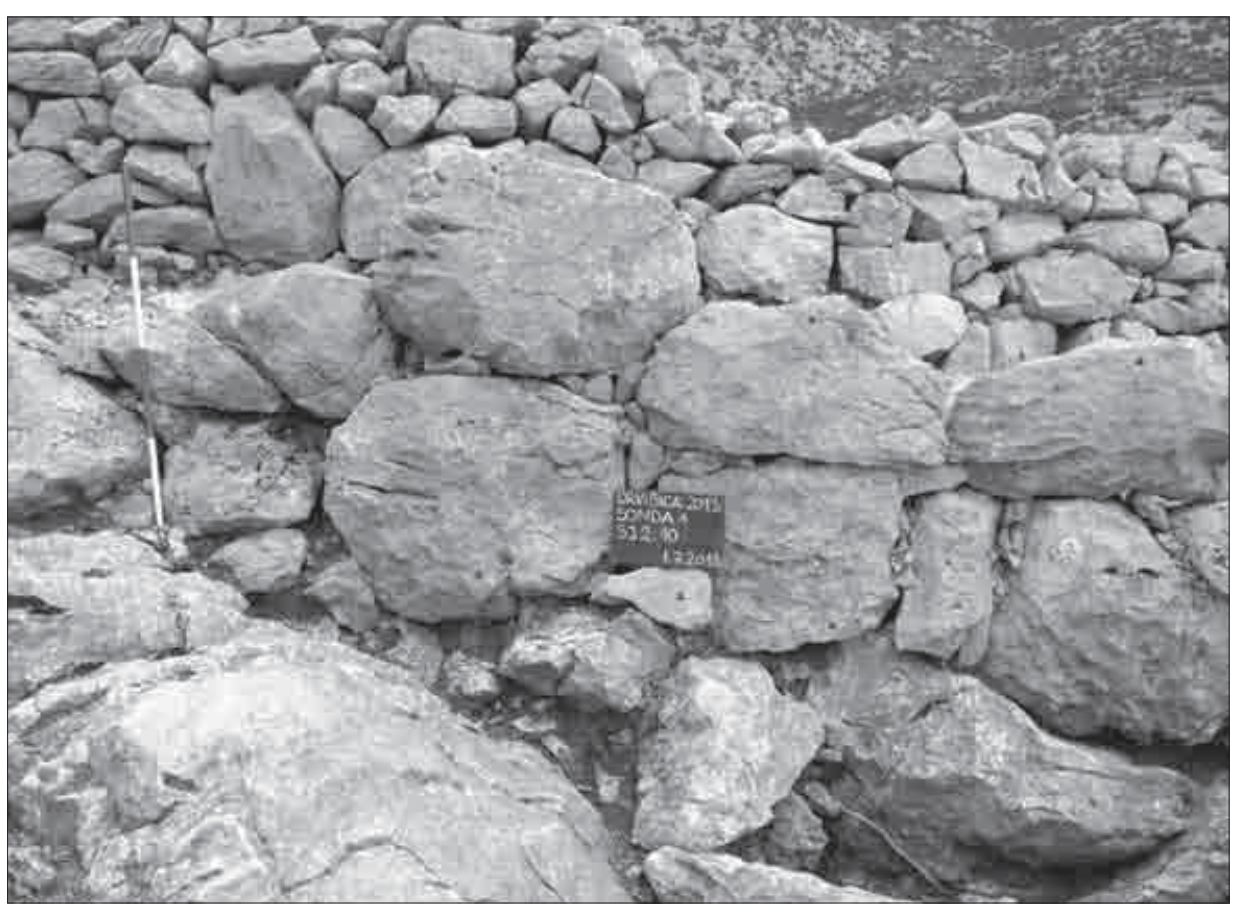

S1. 2. Segment istraženog bedema na gradini Drvišica, foto: V. Glavaš

resurse, pokazuju da najvažnije gradine (Kuk u Senju, Gradina u Svetom Jurju i Drvišica u Karlobagu) nemaju najbolju vidljivost u smislu nadzora šireg teritorija, već su tu ulogu preuzele manje satelitske gradine. Međutim, glavne gradine nadziru najveći broj manjih gradina, od kojih je svaka imala svoju ulogu u vizualnoj kontroli zajedničkog teritorija. ${ }^{16}$

O pogrebnim običajima na prostoru primorske padine Velebita tijekom željeznog doba malo se zna. Do sada su kamene gomile (tumuli) pronađene samo na svetojurskom i karlobaškom području. ${ }^{17}$ Sve su gomile, osim tumula na prijevoju Sinokos, locirane uz gradine ili na gradini. Takvo je pozicioniranje očigledno imalo posebno značenje za željeznodobne zajednice, njihova je gradnja dodatno markirala teritorijalnost i pripadnost određenog prostora zajednici utemeljenoj i na kultu predaka. Budući da gomile nisu istraživane, ${ }^{18}$ teško je definirati njihovu starost i prikupiti više podataka o pojedincima ukapanima u njih.

${ }^{16}$ V. GLAVAŠ, 2014, 12-23.

${ }^{17}$ A. GLAVIČIĆ, 1981-82; V. GLAVAŠ, 2015, 125, 137-138.

${ }^{18}$ Sve gomile pronađene na studijskom području su opljačkane. 


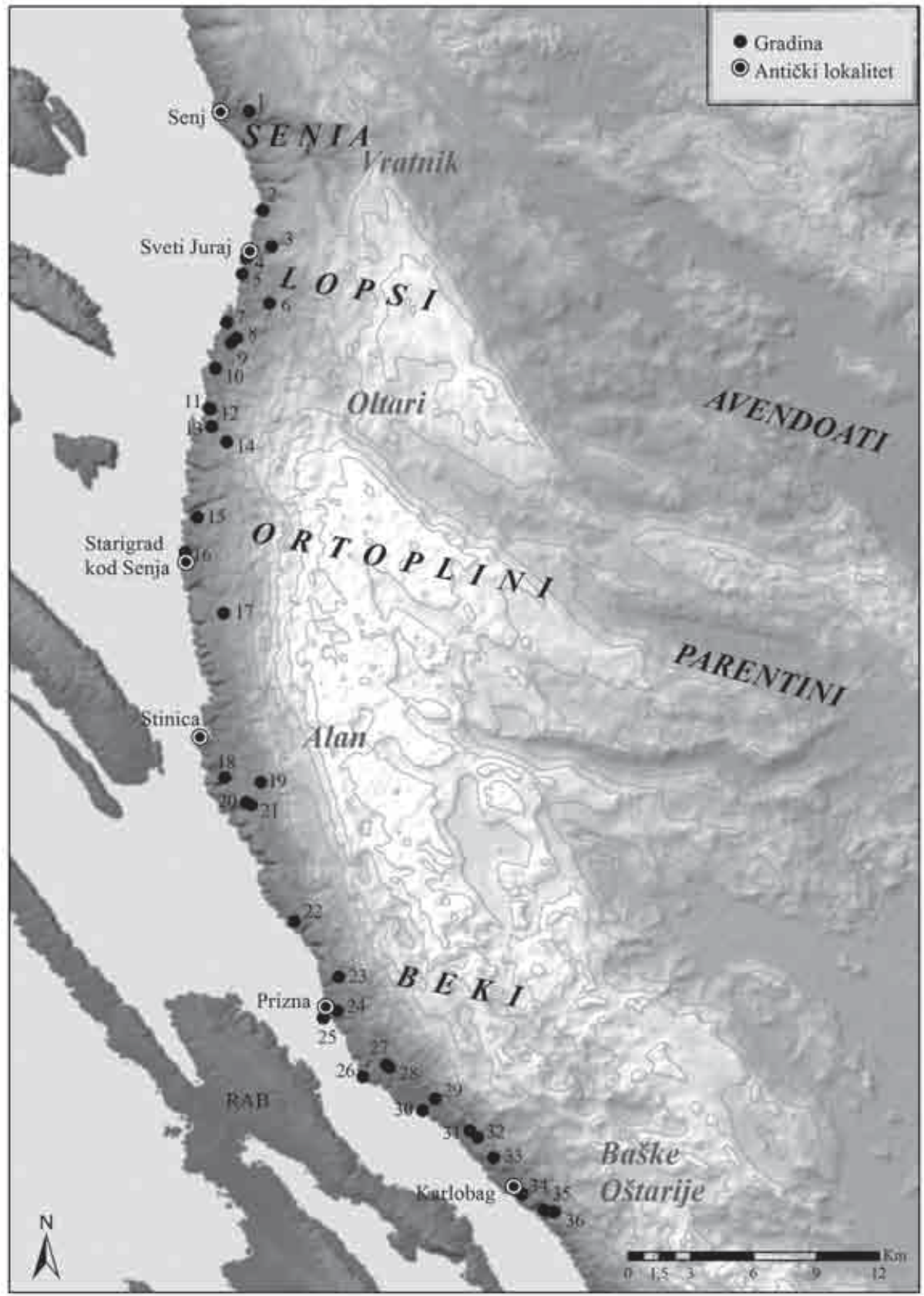

Karta 1. Prapovijesni i antički lokaliteti na studijskom prostoru, izradila: V. Glavaš 
Katalog prapovijesnih lokaliteta:

$\begin{array}{lll}\text { 1. Kuk } & \text { 13. Glavčica } & \text { 25. Gradina } \\ \text { 2. Torina } & \text { 14. Gredina } & \text { 26. Stražbenica } \\ \text { 3. Samograd } & \text { 15. Gradina } & \text { 27. Žuljevača } \\ \text { 4. Gradina } & \text { 16. Gradina } & \text { 28. Žuljevača } \\ \text { 5. Jablanova } & \text { 17. Bela kosa } & \text { 29. Perić glavica } \\ \text { 6. Glavaši } & \text { 18. Klačnica } & \text { 30. Velika glavica } \\ \text { 7. Čelinka } & \text { 19. Baričevića glavica } & \text { 31. Bojna draga } \\ \text { 8. Zagon } & \text { 20. Gradina iznad Smojverske drage } & \text { 32. Tomljenovića glavica } \\ \text { 9. Šikinica } & \text { 21. Josinova glavica } & \text { 33. Živi kuk } \\ \text { 10. Brinovača } & \text { 22. Bilančevica } & \text { 34. Drvišica } \\ \text { 11. Klis } & \text { 23. Lavorina } & \text { 35. Đotluša } \\ \text { 12. Pod Klisom } & \text { 24. Kovači } & \text { 36. Paripovica }\end{array}$

Na Drvišici u Karlobagu dokumentirana je nešto drugačija praksa, koja se očituje u gradnji kružnih suhozidnih konstrukcija s inhumiranim pokojnicima (Sl. 3). Takve grobne strukture datirane analizom grobnih priloga te $\mathrm{C}-14$ analizom kostiju u razdoblje cca 10. -5 . st. pr. Kr., nalaze se na sjevernoj padini gradine, njihov promjer iznosi do $5 \mathrm{~m}$ i pozicionirane su jedna do druge. Iako je gradnja kamene grobne škrinje u svojoj osnovi istovjetna ritusu ukapanja u tumulu, a ideja kruga formiranog u platformu visine do $1 \mathrm{~m}$, vuče tradiciju iz gradnje gomila, njihovo postojanje može ukazivati na društveno elitnu skupinu, koja je gradnjom specifičnih i sofisticiranijih grobnih konstrukcija željela ostvariti svoju vezu sa zajednicom i gradinom i nakon smrti. Budući da je u blizini Drvišice pronađen veliki broj grobova koje tek treba istražiti, za sada možemo samo pretpostaviti da su pokojnici pokopani bliže središtu gradine vjerojatno bili značajniji u društvenoj hijerarhiji, što možemo tumačiti kao naglašavanje elitnog identiteta i nasljednog legitimiteta vlasti nad društvom i mjestom. Time se ujedno poticala i društvena memorija i sjećanje na poznate pretke, čime se stvarala distinkcija od nižeg sloja stanovništva. ${ }^{19}$

\section{Antički kulturni krajolik}

Uspostavom rimske provincijalne uprave i administriranjem prostora $\mathrm{u}$ teritorijalne općine (civitates), mijenja se krajolik, jer stara gradinska središta odumiru vrlo brzo. Raniji decentraliziran obrazac, koji je činilo ukupno 36 gradina, centralizira se na značajna središta: Seniju, Lopsiku, Ortoplu i Vegij. Prostorni raspored podgorskih civitates uvelike je ovisio o geomorfološkim osobitostima planine. To znači da su zajednice strukturirane s obzirom na glavne

${ }^{19}$ V. GLAVAŠ, 2015, 138-139. 


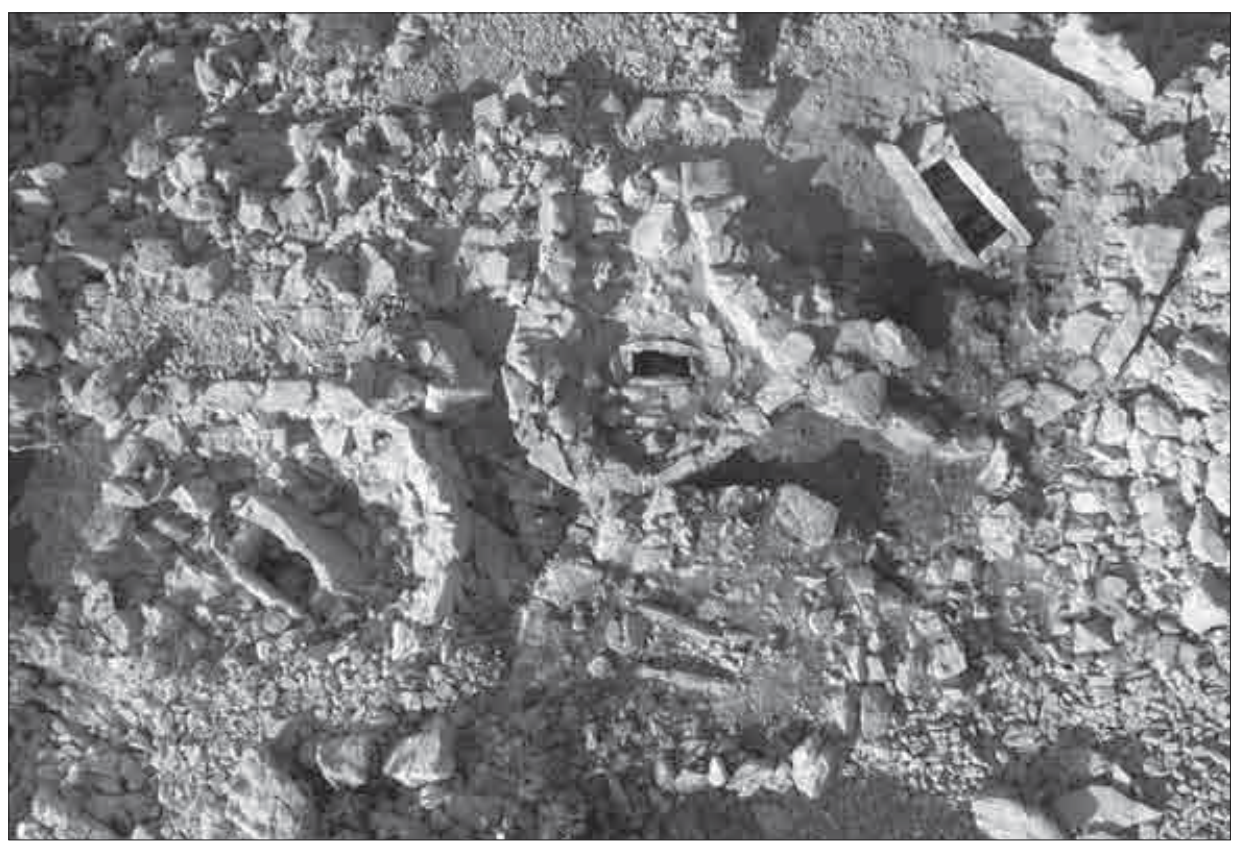

Sl. 3. Dio prapovijesne nekropole na Drvišici, foto: V. Glavaš

fizičko-geografske odrednice, a to su u konkretnom slučaju planinski prijevoji. Razlog takvog strukturiranja su koridori kretanja, koji su vodili preko planinskih prijevoja na drugu stranu planine, ili do planinskih pašnjaka u vršnoj zoni. Zbog toga su prijevoji Vratnik, Oltari, Alan i Baške Oštarije korišteni kao putevi do najznačajnijih resursa zajednice, stoga je posjedovanje takvog prolaza i njegova kontrola bilo od velikog značenja za razvoj zajednice.

Podvelebitska naselja tijekom antike postaju ekonomski subjekti lokalnog ili regionalnog značenja. Među njima ističe se Senija, koja ima regionalnu gospodarsku ulogu ${ }^{20}$ dok su Lopsika, Ortopla i Vegij zadržali lokalno značenje. Navedena su naselja bila upravna središta svojih zajednica i zato su morala posjedovati osnovnu urbanističku formu i zgrade za obavljanje administrativnih funkcija. Međutim, zbog nedostatka istraživanja, to još uvijek nije svuda i potvrđeno. Senija je, naime, jedina bila "tipični" rimski grad s urbanistički organiziranim prostorom te javnim, sakralnim i privatnim građevinama, čiji su arhitektonski ostatci dokumentirani povremenim arheološkim istraživanjima. ${ }^{21} \mathrm{Na}$ temelju prikupljenih podataka

${ }^{20}$ M. GLAVIČIĆ, 2005, 475-478.

${ }^{21}$ M. GLAVIČIĆ, 1995, 1-28; 1995b, 29-80; B. LJUBOVIĆ, 2008, 279-292. 
vidljivo je da je u Seniji gradnja antičkih građevina vršena planski uz poštivanje pravila rimskog urbanizma. ${ }^{22}$ Ostala antička posvelebitska središta, prvenstveno Lopsiku i Vegij, o kojima imamo samo skromne podatke iz nekoliko istraživanja, ${ }^{23}$ ne možemo smatrati gradovima u pravom urbanističkom smislu. Međutim, i ta su naselja s javnim objektima građenim na novi (rimski) način svojim stanovnicima nudila iskustvo zajedničkog centra. U Lopsiki i Vegiju pretpostavljamo postojanje javnih i sakralnih građevina, koje su istodobno predstavljale zajednički rimski identitet i simbolizirale rimsku upravu.

Manje razvijena, lokalna forma urbanizma Lopsike i Vegija sa svega nekoliko javnih građevina, dokaz je prihvaćanja rimske urbane ideologije, koja ipak, zbog slabijeg ekonomskog potencijala, u tim mjestima nije doživjela veći razvoj. Osim ekonomskog stanja, urbanizam je ondje ograničavao i sam fizički krajolik, koji se sporije odazivao na procese društvene promjene nastale uspostavom rimske vlasti. Zbog svojih fizičko-geografskih odrednica, koje nisu pogodovale razvitku tipičnog rimskog grada, takav je kulturni krajolik vrlo inertan i konzervativan. ${ }^{24}$ Stoga su ta naselja svojom prstornom organizacijom, načinom izgradnje i općenitim izgledom imitirala strukturu urbanizma, čime su činila prepoznatljive centre svojih civitates. Međutim, u tome je u potpunosti uspjela jedino Senija.

Urbanizam je svakako jedna od glavnih posljedica romanizacije. Međutim, osim toga što je bio posljedica, urbanizam je i poticao romanizaciju stanovništva. Izgradnja monumentalnih zgrada, koje se prvi put pojavljuju s romanizacijom, te upotreba novih tehnika i struktura gradnje, koje omogućavaju znatno kvalitetniju gradnju s obzirom na raniju suhozidnu tehniku, utjecali su na nova iskustva autohtonog stanovništva. Upravo su monumentalne zgrade, natpisi i skulpture implicirale moć nove uprave i pojačavale njezino značenje. Senija je jedina u podvelebitskom primorju vrlo rano razvila urbanističku sliku grada ${ }^{25}$ čime je postala pokretač romanizacije u podvelebitskom primorju. Zbog toga je slika urbaniziranog grada odražavala poruke lokalne elite aktivno uključene u administrativni, religijski i građanski život, i koja je simbolizirala državni i carski autoritet na svom području. Urbanizam kao struktura, koja je prihvaćena u podvelebitskom središtima, ali koja nije u potpunosti uspjela zbog gospodarskih i geomorfoloških čimbenika, ipak je povezao podvelebitski prostor u globalnu strukturu rimske države. Prihvativši rimski način življenja u urbanoj sredini, lokalno je stanovništvo počelo dijeliti

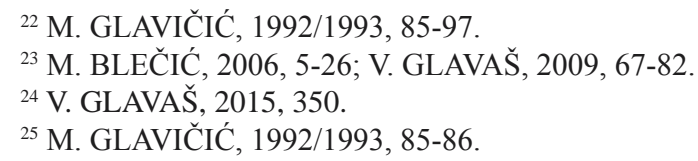


zajednički rimski identitet. Elita je urbanizam, kao i sve ostale strukture rimske uprave, prihvatila iz više razloga. Novi način gradnje nudio je znatno udobniji život. Međutim, novi objekti i luksuzna stambena arhitektura postali su i način izražavanja elitnog položaja, koji je slao snažne poruke o statusu pojedinca u društvenoj zajednici. Stoga su natpisi o pojedinim munificijencijama postali značajan segment urbanog krajolika, ${ }^{26}$ ali i način isticanja identiteta pojedinaca, koji su gradnjom pokazivali svoj društveni status i lojalnost rimskoj upravi.

\section{Zaključak}

Teškoje objasniti mehanizme koji su doveli do potpunog napuštanja gradina tijekom 1. st. Jedan od razloga jest činjenica da su one, kao glavni obrambeni, teritorijalni i identitetski faktor autohtonih zajednica u novom upravnom okviru zasigurno postale nefunkcionalne. Uspostavom municipija, koji se razvijaju podno velebitskih prijevoja, rimska vlast je vrlo praktično uspostavila kontrolu nad starim tradicionalnim sferema utjecaja autohtonih zajednica, koja su postala gradskim središtima većeg ili manjeg značenja. Tako su sve osnovne aktivnosti koncentrirane u središtima, Seniji, Lopsiki, Ortopli i Vegiju, i zato je ubrzo došlo i do napuštanja starih gradina.

U novom upravnom okviru Senija, Lopsika, Ortopla i Vegij postaju instrumentima romanizacije autohtonih zajednica podvelebitskog primorja te će tijekom antike funkcionirati kao upravni, religijski i kulturni centri svoje zajednice. Novi naseobinski obrazac koji nastaje nakon uspostave rimske uprave izravna je posljedica romanizacije prostora i nove društveno-ekonomske dinamike, a očituje se u centraliziranju aktivnosti prema spomenutim centrima te postupnom napuštanju prethodno naseljenih područja. Senija pritom, tijekom čitave antike, zadržava vodeću trgovačku i gospodarsku ulogu, dok ostala naselja zadržavaju isključivo lokalno značenje.

\section{Literatura}

Šime BATOVIĆ, Kasno brončano doba na istočnom Jadranskom primorju. Praistorija jugoslovenskih zemalja, IV, Sarajevo, 1983, 271-374.

Martina BLEČIĆ, Zaštitno arheološko istraživanje u Sv. Jurju, Senjski zbornik, 33, Senj, 2006, 5-26.

Josip BRUNŠMID, Arheološke bilješke iz Dalmacije i Panonije II, Vjesnik Arheološkog muzeja u Zagrebu, n. s. 3, Zagreb, 1898, 149-190.

${ }^{26}$ M. GLAVIČIĆ, 1994b, 55-82. 
Josip BRUNŠMID, Groblje bronsanoga doba na Klaćenici kod Jablanca (kotar Senj). Povjest mjesta Jablanca, Vjesnik Arheološkog muzeja u Zarebu, 5, Zagreb, 1901, 53-62.

Aleksandra FABER, Sveti Juraj - Lopsica i Lopci, Senjski zbornik, 30, Senj, 2003, 629648.

Stašo FORENBAHER, Tragovi služenja brončanodobnom pećinom Separovačom kod Donje Klade, Senjski zbornik, 18, Senj, 1991, 217-225.

Stašo FORENBAHER - Pavle VRANJICAN, Vaganačka pećina, Opuscula archaeologica, 10, Zagreb, 1985, 1-21.

Vedrana GLAVAŚ, Crkva sv. Filipa i Jakova u Sv. Jurju, rezultati novih istraživanja, Senjski zbornik, 36, Senj, 2009, 67-82.

Vedrana GLAVAŠ, Prometno i strateško značenje prijevoja Vratnik u antici, Senjski zbornik, 37, Senj, 2010, 5-18.

Vedrana GLAVAŠ, Problems of reconnaissance of the karst landscape - an example of the northern sub-Velebit littoral, Croatia, AARG News, The newsletter of the Aerial Archaeology Research Group, 43, 2011, 24-29.

Vedrana GLAVAŠ - Rog PALMER, Aerial and field reconnaissance of Velebit mountain, Aerial archaeology and remote sensing from Baltic to the Adriatic, Selected Papers of the Annual Conference of the Aerial Archaeology Research Group, 13th15th September 2012, Budapest, Hungary, Institute of Archaeological Sciences, Faculty of Humanities, Eötvös Loránd University, Budapest, 2013, 19-23.

Vedrana GLAVAŠ, Analize vidljivosti u prapovijesnom krajoliku Velebita, Archaeologia Adriatica, 8, Zadar, 2014, 1-26.

Vedrana GLAVAS̆, Romanizacija autohtonih civitates na prostoru sjevernog i srednjeg Velebita. doktorski rad, Zadar, 2015.

Vedrana GLAVAŠ - Aleš GRLJ, Rekonstrukcija ozemelj prazgodovinskih skupnosti na prostoru severnega in srednjega Velebita z uporabo GIS-ov, Dela - Oddelek za geografijo Filozofske fakultete v Ljubljani, 45, Ljubljana, 2016, 65-81.

Ante GLAVIČIĆ, Arheološki nalazi iz Senja i okolice (I), Senjski zbornik, 2, Senj, 1966, 383-418.

Ante GLAVIČIĆ, Arheološki nalazi iz Senja i okolice (II), Senjski zbornik, 3, Senj, 1967-1968, 5-45.

Ante GLAVIČIĆ, Arheološki nalazi iz Senja i okolice (III), Senjski zbornik, 4, Senj, 1970, 45-70.

Ante GLAVIČIĆ, Izvještaj o arheološkom nalazu ranorimskih grobova u vrtu DIP-a Olivieri u Senju godine 1975, Senjski zbornik, 6, Senj, 1975, 211-218.

Ante GLAVIČIĆ, Arheološki nalazi iz Senja i okolice (IV), Senjski zbornik, 8, Senj, 1980, 171-186.

Ante GLAVIČIĆ, Nalazi kamenih gromila na Velebitu (I dio), Senjski zbornik, 9, Senj, 1981-1982, 33-42.

Ante GLAVIČIĆ, Arheološki nalazi iz Senja i okolice (V), Senjski zbornik, 9, Senj, 1981-1982, 63-90.

Ante GLAVIČIĆ, Arheološki nalazi iz Senja i okolice (VI), Senjski zbornik, 10-11, Senj, 1984, 7-28.

Miroslav GLAVIČIĆ, Željeznodobna i antička naselja podno Velebit, Radovi Filozofskog fakulteta u Zadru, 31(18), Zadar, 1991/1992, 97-119. 
Miroslav GLAVIČIĆ, Prilozi proučavanja poleogeneze i urbanističkog razvoja antičke Senije, Radovi Filozofskog fakulteta u Zadru, 32 (19), Zadar, 1992/1993, 79-104. Miroslav GLAVIČIĆ, Značenje Senije tijekom antike, Senjski zbornik, 21, Senj, 1994, 41-58.

Miroslav GLAVIČIĆ, Natpisi antičke Senije, Radovi Filozofskog fakulteta u Zadru, 33 (20), Zadar, 1994b, 55-82.

Miroslav GLAVIČIĆ, Izvješče o provedenim sondažnim arheološkim istraživanjima pri uređenju pločnika u ulici P. Rittera Vitezovića i I. Hreljanovića tijekom veljače i ožujka 1995., Senjski zbornik, 22, Senj, 1995, 1-28.

Miroslav GLAVIČIĆ, Izvješče o arheološkom nadzoru i zaštitnom istraživanju na prostoru izgradnje školske športske dvorane u Senju, Senjski zbornik, 22, Senj, 1995b, 29-80.

Miroslav GLAVIČIĆ, Civitas - municipium Lopsica, Radovi Filozofskog fakulteta u Zadru, 35 (22), Zadar, 1995c, 45-70.

Miroslav GLAVIČIĆ, Gospodarsko značenje antičke Senije, Histria Antiqua, 13, Pula, 2005, 475-478.

Blaženka LJUBOVIĆ, Arheološka istraživanja na prostoru bivšeg vrta Olivieri u Senju, Senjski zbornik, 35, Senj, 2008, 279-292.

Mate SUIĆ, Antički grad na istočnom Jadranu, Zagreb, 2003.

Marin ZANINOVIĆ, Antička naselja ispod Velebita, Senjski zbornik, 8, Senj, 1980, 187-196.

\section{THE POPULATION COVERAGE OF NORTHERN AND CENTRAL VELEBIT IN PREHISTORY AND ANTIQUITY}

\section{Summary}

Presented in the paper are the results of the research of the prehistoric and ancient population coverage of the area of northern and central Velebit.

The research of the population coverage is just one part of the multidisciplinary studies of the cultural landscape, which has been a study area for the last ten years. The methodology of the research is complex and includes intensive field surveys, aerial photography, GIS analysis and archaeological excavations.

The form of prehistoric settlements is characterised by hillforts, of which 36 have been documented in the study area to date. Although in earlier literature they were mostly treated as residential sites, at the 36 sub-Velebit hillforts settlement activities have not been documented. The basic architectural structures characteristic for the sub-Velebit hillforts are ramparts and terraces.

The spatially decentralised form of the hillfort in the sub-Velebit littoral after the establishment of Roman administration is centralised, and at the foot of the Velebit saddles municipal centres developed: Senia, Lopsica, Ortopla and Vegium. At the same time, Senija achieved a leading economic, trade and transport role of regional significance, whilst the other settlements retained only local significance.

Keywords: Velebit, prehistory, hillforts, Antiquity, population coverage 